\title{
Pengaruh Model Pembelajaran Attention, Relevance, Confidence and Satisfaction (ARCS) terhadap Kemampuan Berpikir Matematis berdasarkan Taksonomi Bloom Revisi
}

\author{
Resti Yelma Sari ${ }^{1}$, Netriwati ${ }^{2}$, Fraulein Intan Sari ${ }^{3}$
}

1,2,3 UIN Raden Intan Lampung

Correspondence: $\triangle$ restiyelmasari@gmail.com

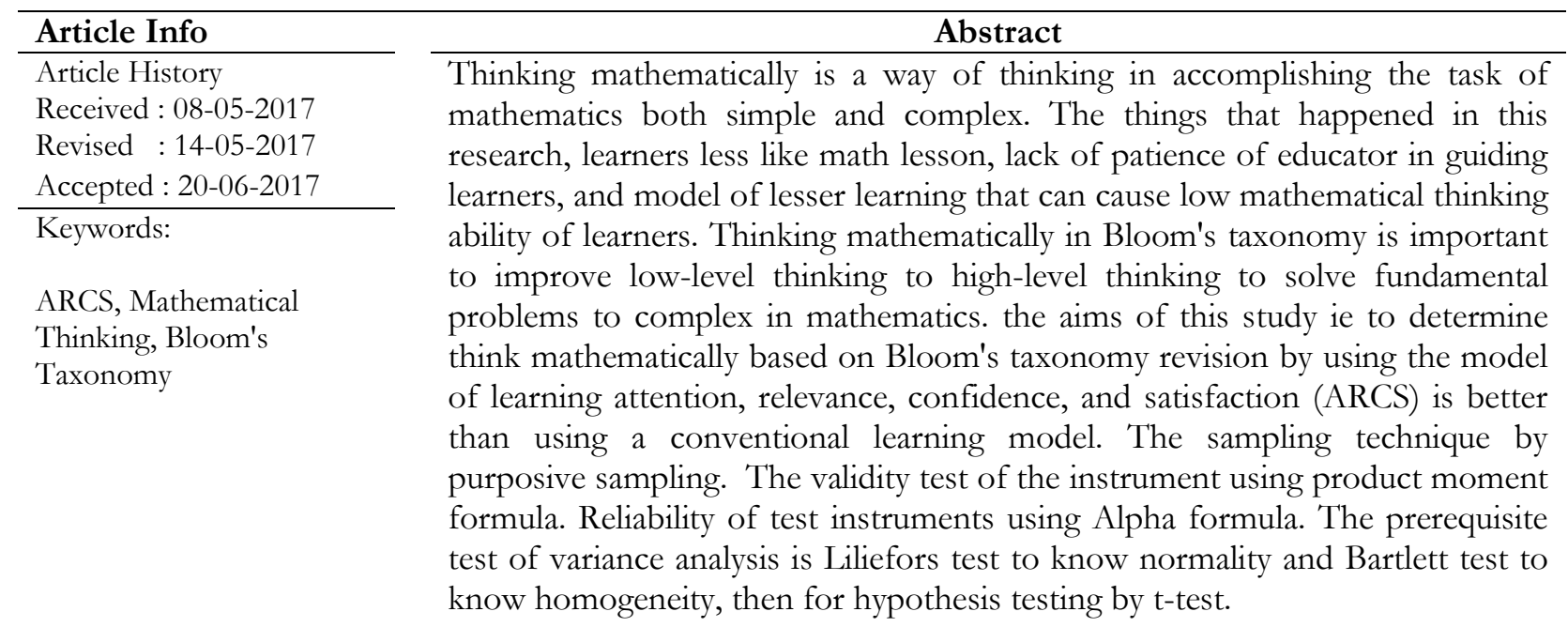

\section{PENDAHULUAN}

Berpikir matematis (mathematical thinking) diartikan sebagai cara berpikir berkenaan dengan proses matematika (doing math) atau cara berpikir dalam menyelesaikan tugas matematika (mathematical task) baik yang sederhana maupun yang kompleks. Berdasarkan Peraturan Pemerintah Republik Indonesia Nomor 19 Tahun 2005 tentang Standar Nasional Pendidikan pasal 26 ayat (2) bahwa standar kompetensi lulusan pada satuan menengah umum bertujuan untuk meningkatkan kecerdasan, pengetahuan, kepribadian, ahlak mulia, serta keterampilan untuk hidup mandiri dan mengikuti pendidikan lebih lanjut. Selain itu, kurikulum di Indonesia berorientasi pada pencapaian kompetensi yang merupakan upaya mempersiapkan peserta didik agar memiliki kemampuan intelektual, emosional, spiritual, dan sosial yang bermutu tinggi. Telah dijelaskan bahwa salah satu tujuan pendidikan adalah meningkatkan pengetahuan atau kemampuan intelektual dimana pada aspek tersebut merupakan kawasan kognitif atau kemampuan berpikir peserta didik.

Beberapa hasil penelitian yang penulis baca baik penelitian di dalam negeri dan penelitian di luar negeri, diantaranya penelitian di luar negeri, menurut Tall kemajuan berpikir matematis berkaitan dengan konsep yang sudah ada pada siswa dan belajar dari cara perkumpulan. Untuk mencapai tingkat 
kemajuan pemikiran matematis, Tall menyatakan bahwa konsep adalah pengetahuan tertentu yang mana individu dapat menjelaskan atau berlatih untuk memperoleh teori, rumus dan ketakutan dari matematika. Kemajuan berpikir matematis tidak hanya membutuhkan penciptaan pengetahuan tetapi juga peningkatan pengetahuan. Penelitian yang sama juga di lakukan oleh Mary Kay Stein, Barbara W.Grover, Marjorie Heningsein menyatakan bahwa pemberian tugas dapat menuntut siswa berpikir matematis yang lebih maju dan penalaran yang lebih baik.

Sedangkan hasil penelitian di dalam negeri, Nohda, Shigeo dan Henningsen \& Stein menemukan beberapa hal yang harus diperhatikan guru dalam pembelajaran matematika, yaitu: jenis berpikir matematis harus sesuai dengan siswa, jenis bahan ajar, manajemen kelas, peran guru, serta otonomi siswa dalam berpikir dan beraktivitas. Selain itu, penelitian yang dilakukan Maya Kusuma Ningrum dan Abdul Aziz Saefudin menyimpulkan bahwa pembelajaran matematika tidak hanya cukup pada pencapaian kemampuan matematika dasar, tetapi mulai untuk berubah ke pola pikir baru bahwa pembelajaran dirancang untuk mencapai kemampuan berpikir tingkat tinggi. Dari beberapa penelitian tersebut dapat disimpulkan bahwa peran pendidik dalam membangun penalaran dan berpikir matematis peserta didik sangat penting. Menurut Katagiri yang dikutip dari Aryadi Wijaya bahwa pengembangan kemampuan berpikir matematis telah menjadi perhatian utama dalam pembelajaran matematika di Jepang. Terkait dengan berpikir matematis penulis menggunakan suatu taksonomi untuk mengetahui proses berpikir matematis siswa. Taksonomi belajar dikenal dengan istilah Taxonomy Bloom.

Taksonomi Bloom yang digunakan adalah taksonomi Bloom yang telah direvisi oleh Lorin W.Anderson. Dalam Revisied Taxonomy, Anderson dan Krathwol melakukan revisi pada kawasan kognitif. Menurutnya terdapat dua kategori, yaitu dimensi proses kognitif dan dimensi pengetahuan.

Berdasarkan nilai ujian matematika peserta didik kelas XI IPA SMA Negeri 14 Bandar Lampung ternyata banyak peserta didik yang belum mencapai KKM. Kriteria Ketuntasan Minimal (KKM) di SMA Negeri 14 Bandar Lampung yakni 76. Peserta didik yang memperoleh hasil belajar di atas nilai KKM adalah 17 dengan persentase 21\% dari 78 peserta didik, sedangkan peserta didik yang memperoleh hasil belajar dibawah KKM ada 61 dengan persentase $79 \%$ dari 78 peserta didik. Hasil prapenelitian ditemukan bahwa kemampuan berpikir matematis peserta didik umumnya masih rendah.

Hasil pra-penelitian tersebut sejalan dengan permasalahan yang ditemukan dari hasil wawancara dan observasi yaitu peserta didik tidak menyukai pelajaran matematika disebabkan oleh suasana pembelajaran yang menegangkan mengakibatkan siswa merasa takut dalam pembelajaran. Hal ini sesuai dengan penelitian yang dilakukan oleh Indra Martha Rusmana, permasalahan yang sering hadir dalam pembelajaran matematika bahwa sebagian peserta didik masih kurang termotivasi dalam belajar matematika. Peserta didik masih beranggapan bahwa matematika merupakan pelajaran yang sulit, sukar, dan menegangkan. Katagiri menyebutkan bahwa salah satu kendala yang dihadapi adalah sikap apatis guru terhadap pengembangan kemampuan berpikir matematis. Hal yang sama juga terlihat bahwa kurangnya perhatian pendidik pada proses pembelajaran disebabkan kurangnya kesabaran pendidik dalam membimbing peserta didik yang mempunyai kemampuan lemah mengakibatkan peserta didik merasa rendah diri.

Sekian banyaknya permasalahan yang terjadi maka penulis menggunakan model pembelajaran yang sesuai dengan tujuan pembelajaran dengan harapan permasalahan tersebut dapat teratasi. Model pembelajaran yang dapat diterapkan untuk melibatkan siswa lebih aktif dan termotivasi dalam proses 
pembelajaran salah satunya adalah ARCS. Model pembelajaran ARCS yang merupakan akronim dari Attention (Perhatian), Relevance (Keterkaitan), Confidence (Percaya Diri)danSatisfaction (Kepuasan)dimulai dengan pemberian motivasi dan memfokuskan siswa pada pelajaran tersebut.

Model ARCS terbukti dapat mengatasi beberapa permasalahan yang ada di dunia pendidikan. Beberapa hasil penelitian yang penulis baca baik penelitian di dalam negeri dan penelitian di luar negeri, diantaranya penelitian di dalam negeri yang dilakukan oleh Zulfira Irsyaf menyimpulkan bahwa metode Attention Relevance Confidence and Satisfaction (ARCS) dapat meningkatkan aktivitas belajar. Hal yang sama juga dilakukan oleh Stefany Maya Evy menyimpulkan bahwa strategi pembelajaran ARCS secara optimal dapat memberikan dampak positif dalam upaya meningkatkan motivasi belajar dan hasil belajar siswa. Sedangkan penelitian yang dilakukan oleh Siti Masfuah menyimpulkan bahwa metode pictorial riddle melalui pembelajaran ARCS dapat meningkatkan kemampuan pemecahan masalah dan motivasi berprestasi siswa. Hasil penelitian di luar negeri, Hermann Astleitner menyatakan bahwa pendekatan ARCS dapat meningkatkan self-regulated learning peserta didik. Hal yang sama juga dilakukan oleh Sangeeta Malik menyatakan bahwa model ARCS dapat meningkatkan motivasi untuk mengatasi tingkat penyelesaian tugas. Dari beberapa penelitian menunjukkan variabel-variabel bermasalah di lapangan, dengan model pembelajaran ARCS menjadikan solusi awal dalam menangani permasalah di lapangan.

\section{METODE PENELITIAN}

Metode penelitian yang digunakan adalah penelitian eksperimen. Jenis eksperimen yang akan digunakan adalah Quasy Experimental Design yaitu untuk memperoleh informasi yang merupakan perkiraan bagi informasi yang dapat diperoleh dengan eksperimen yang sebenarnya dalam keadaan yang tidak memungkinkan untuk mengontrol semua variabel yang relevan.

Penelitian ini responden dikelompokkan menjadi dua kelompok. Kelompok pertama adalah kelompok eksperimen, yaitu peserta didik yang mendapat perlakuan pembelajaran matematika dengan model pembelajaran ARCS (Attention, relevance, Confidence and Satisfaction). Kelompok kedua adalah kelompok kontrol, yaitu peserta didik yang mendapatkan perlakuan pembelajaran matematika dengan metode konvensional. Subjek pada penelitian ini adalah peserta didik kelas XI IPA SMA Negeri 14 Bandar Lampung. Pengambilan sampel menggunakan teknik purposive sampling. Dalam penelitian ini diambil dua kelas yaitu XI IPA 3 sebagai kelas eksperimen ARCS dan XI IPA 4 sebagai kelas kontrol konvensional. Prosedur dari penelitian ini adalah tahap persiapan, pada tahap ini penulis mempersiapkan perangkat pembelajaran dan soal tes yang kemudian di validasi oleh 2 dosen pendidikan matematika dan 1 guru matematika. Kemudian soal tersebut di uji coba pada peserta didik untuk mengukur validitas, realibilitas, tingkat kesukaran, dan daya pembeda. Tahap pelaksanaan, pada tahap ini penulis menggunakan model ARCS, pada pertemuan terakhir penulis memberikan tes soal untuk mengukur kemampuan berpikir matematis taksonomi Bloom revisi kepada kelas eksperimen dan kelas kontrol. Tahap analisis data, pada tahap ini adalah mengelola data yang diperoleh dari hasil pelaksanaan. Data yang dibutuhkan pada penelitian ini adalah data kemampuan berpikir matematis peserta didik berdasarkan taksonomi Blooom revisi. Untuk mengetahui pengaruh model ARCS terhadap kemampuan berpikir matematis berdasarkan taksonomi Bloom revisi dilakukan analisis data menggunakan uji normalitas (Liliefors) dan uji homogenitas (Bartlet). Kemudian jika kedua asumsi terpenuhi maka uji hipotesis penelitian ini menggunakan uji-t tidak berkorelasi. 


\section{HASIL DAN PEMBAHASAN}

Kemampuan berpikir matematis berdasarkan taksonomi Bloom revisi peserta didik dapat dilihat dari hasil tes yang telah dianalisi oleh penulis. Hasil tes yang diharapkan adalah terdapat pengaruh model ARCS terhadap kemampuan berpikir matematis berdasarkan taksonomi Bloom revisi peserta didik. Penulis mengumpulkan data-data hipotesis dengan mengajar materi komposisi fungsi sebanyak 3 kali pertemuan. Kemudian untuk tes dilakukan pada akhir pertemuan, yaitu pertemuan ke-4.

Pertemuan pertama pada tanggal 11 Maret 2017, membahas tentang syarat dan aturan fungsi yang dapat dikomposisikan dan menentukan fungsi komposisi dari beberapa fungsi. Pertemuan pertama pada kelas eksperimen dilakukan pada jam pertama dari jam 07.15 - 08.45 WIB. Pada kelas eksperimen diterapkan model pembelajaran ARCS. Pada awal pertemuan, penulis menanyakan kabar peserta didik, mengabsen peserta didik, dilanjutkan dengan menginformasikan SK dan KD serta tujuan pembelajaran menggunakan LCD merupakan komponen dari model ARCS yaitu Attention. Pada pertemuan ini peserta didik diberikan perhatian (Attention) dan relevansi pembelajaran (Relevance) berupa tanya jawab mengenai materi sebelumnya dan penayangan gambar yang menarik tentang fungsi komposisi menggunakan LCD, berkaitan dengan kehidupan sehari-hari peserta didik. Banyak peserta didik yang bertanya-tanya dengan gambar tersebut. Kemudian untuk menarik perhatian peserta didik, penulis memberikan tanya jawab mengenai penayangan gambar tersebut merupakan salah satu komponen model ARCS yaitu Attention. Sebelumnya penulis memberikan sedikit petunjuk kepada peserta didik untuk memecahkan masalah, merupakan salah satu komponen ARCS yaitu Confidence. Setelah diberikan sedikit petunjuk, ada beberapa peserta didik yang mampu memecahkan masalah dari penayangan gambar tersebut. Kemudian untuk meningkatkan kepercayaan diri peserta didik, maka peserta didik tersebut diminta maju ke depan kelas untuk menjelaskan maksud dari penayangan gambar tersebut, karena peserta didik mampu menjelaskan kepada teman-temannya maka peserta didik diberikan penambahan nilai. Dari keberanian peserta didik tersebut dapat menumbuhkan rasa kepuasan dan kepercayaan diri peserta didik yang merupakan komponen model ARCS yaitu Confidence dan Satisfaction. Sehingga penulis lebih menggunakan pendekatan yang berpusat pada siswa. Kemudian penulis membagikan LKS yang berkaitan dengan model ARCS. Peserta didik diberikan kebebasan untuk mendiskusikan LKS tersebut dengan teman sebangkunya saja. Disela-sela pembelajaran, penulis memberikan permainan atau game kepada peserta didik yaitu menghubungkan 9 titik menjadi 4 garis yang tidak terputus dan tidak ganda. Banyak peserta didik yang maju mencoba mengerjakan tetapi belum berhasil dan kemudian ada salah seorang peserta didik yang berhasil menjawab permainan tersebut. Kemudian peserta didik tersebut diberikan reward. Peserta didik merasa senang dan tidak jenuh dengan game yang diberikan, ini merupakan salah satu komponen dari model ARCS yaitu Attention,Confidence, dan Satisfaction. Setelah LKS dikerjakan oleh peserta didik, penulis juga memberikan kesempatan kepada beberapa peserta didik untuk menjelaskan di depan kelas dan kemudian diberikan penambahan nilai, ini merupakan salah satu komponen ARCS yaitu Confidence dan Satisfaction.

Pertemuan pertama pada kelas kontrol dilaksanakan pada jam ketiga dari pukul 0.8.45 - 10.15 WIB. Pada awal pertemuan penulis mengabsen peserta didik. Pembelajaran pada kelas kontrol menggunakan model pembelajaran konvensional. Penulis menjelaskan materi tersebut kepada peserta didik dengan menerangkan di depan papan tulis, setelah itu penulis memberikan latihan soal pada LKS 
yang dimiliki peserta didik. Penulis juga memberikan bantuan jika peserta didik masih merasa bingung dengan apa yang telah dijelaskan.

Pertemuan kedua pada tanggal 16 Maret 2017, membahas tentang sifat-sifat komposisi fungsi dan menentukan komponen pembentuk fungsi komposisi. Pertemuan kedua pada kelas eksperimen dilakukan pada jam ketiga dari jam 08.45 - 10.15 WIB. Pada pertemuan kedua, diawal pembelajaran penulis mengabsen kembali peserta didik, dilanjutkan dengan menginformasikan SK dan KD serta tujuan pembelajaran menggunakan LCD, merupakan komponen dari ARCS yaitu Attention. Pada pertemuan ini, penulis sedikit sulit mengkondisikan peserta didik dikarenakan sedang berlangsung kegiatan pentas seni kelas XII, sehingga sedikit mengganggu konsentrasi peserta didik. Penulis membagikan LKS berkaitan dengan model ARCS kepada setiap peserta didik. Kemudian peserta didik mulai mengerjakan dan memahami LKS tersebut, ini merupakan komponen Relevance. Penulis juga membantu peserta didik yang masih kesulitan dalam memahami dan mengerjakan LKS, ini merupakan komponen Confidence. Peserta didik juga diberikan batas waktu 20 menit untuk menyelesaikan soal pada LKS tersebut, merupakan komponen Confidence. Setelah selesai mengerjakan LKS, penulis memberikan game atau permainan berupa game 3, 6, 9 tepuk tangan untuk menarik perhatian peserta didik. Peraturan yang penulis berikan bahwa peserta didik yang salah dan tidak konsentrasi akan dikenakan sanksi menjelaskan soal LKS yang telah dikerjakan, merupakan komponen Attention. Kemudian suasana pembelajaran menjadi ceria karena banyak peserta didik yang tidak berkonsentrasi dalam pembelajaran, sehingga peserta didik mulai berkonsentrasi dan tidak terpengaruh dengan pentas seni tersebut. Sesuai peraturan maka peserta didik yang salah, maju untuk menjelaskan kepada peserta didik lainnya dan diberikan penambahan nilai dan reward, merupakan komponen Confidence dan Satisfaction.

Pertemuan kedua pada kelas kontrol dilaksanakan pada jam kelima dari pukul 10.30 - 12.00 WIB. Pada awal pertemuan penulis mengabsen peserta didik. Pembelajaran pada kelas kontrol menggunakan model pembelajaran konvensional. Penulis menjelaskan materi syarat dan aturan fungsi yang dapat dikomposisikan dan menentukan fungsi komposisi dari beberapa fungsi. Penulis menerangkan beberapa contoh yang terdapat di LKS yang peserta didik miliki, setelah itu penulis memberikan latihan soal pada LKS yang dimiliki peserta didik. Penulis juga memberikan bantuan jika peserta didik masih merasa bingung dengan apa yang telah dijelaskan.

Pertemuan ketiga pada tanggal 18 Maret 2017, membahas tentang fungsi invers. Pertemuan ketiga pada kelas eksperimen dilakukan pada jam pertama dari jam 07.15 - 08.45 WIB. Pada pertemuan ketiga, diawal pembelajaran penulis mengabsen kembali peserta didik, dilanjutkan dengan menginformasikan SK dan KD serta tujuan pembelajaran menggunakan LCD merupakan komponen dari ARCS yaitu Attention. Pada pertemuan kali ini penulis menayangkan video fungsi invers untuk menarik perhatian dan kemampuan berpikir peserta didik, merupakan komponen Attention. Setelah selesai menonton fungsi invers, penulis membagikan LKS kepada peserta didik, merupakan komponen Confidence. Peserta didik diminta untuk menjawab LKS dan menceritakan tentang penayangan fungsi invers tersebut. Kemudian penulis membagikan kelompok untuk mendiskusikan LKS tersebut. Uniknya syarat dari diskusi ini penulis mewajibkan ketua kelompok membantu menjelaskan kepada anggota-anggotanya yang belum paham hingga anggotanya paham, merupakan komponen dari ARCS yaitu Confidence. Penulis memberikan tantangan kepada peserta yang bersedia menjadi ketua kelompok dengan penambahan nilai yang lebih besar dari pada anggotanya, merupakan komponen Attention dan 
Satisfaction. Ternyata ada beberapa peserta didik yang berani bertanggung jawab menjadi ketua kelompok. Kemudian penulis membagi kelompok peserta didik. Setelah itu, peserta didik mendiskusikan LKS yang telah diberikan. Penulis juga membantu kelompok-kelompok yang masih kesulitan dalam memahami dan mengerjakan LKS, merupakan komponen Confidence. Kemudian penulis meminta kelompok-kelompok untuk menjelaskan hasil diskusinya, karena semua kelompok ingin menjelaskan dan mendapatkan nilai, maka penulis menggunakan game atau permainan berupa memberikan permainan LCT berisi pertanyaan-pertanyaan yang menggunakan logika. Banyak kelompok yang salah dalam menjawab pertanyaan tersebut, merupakan komponen Attention. Kelompok yang menjawab dengan benar kemudian menjelaskan soal-soal yang telah didiskusikan ke depan kelas dan diberikan penambahan nilai, merupakan komponen Confidence dan Satisfaction.

Pertemuan ketiga pada kelas kontrol dilaksanakan pada jam ketiga dari pukul 08.45 - 10.15 WIB. Pada awal pertemuan penulis mengabsen peserta didik. Pembelajaran pada kelas kontrol menggunakan model pembelajara konvensional. Penulis menjelaskan materi fungsi invers. Penulis menerangkan beberapa contoh yang terdapat di LKS yang peserta didik miliki, setelah itu penulis memberikan latihan soal pada LKS yang dimiliki peserta didik. Penulis juga memberikan bantuan jika peserta didik masih merasa bingung dengan apa yang telah dijelaskan.

Pertemuan keempat pada tanggal 25 Maret 2017, pada pertemuan ini penulis memberikan tes kemampuan berpikir matematis berdasarkan taksonomi Bloom revisi yang telah valid, reliabel, tingkat kesukaran dan daya pembeda di kelas eksperimen dan kelas kontrol. Pada kelas eksperimen dilaksanakan pada jam pertama pukul 07.15-08.45 WIB. Sedangkan pada kelas eksperimen dilaksanakan pada jam ketiga pukul 08.45-10.15 WIB.

Berdasarkan pemaparan di atas, diperoleh hasil normalitas dengan menggunakan uji Liliefors yang menunjukkan bahwa sampel berasal dari populasi yang berdistribusi normal, karena data berdistribusi normal, maka dilanjutkan dengan analisis uji homogenitas menggunakan uji Bartlet, diketahui bahwa kelas eksperimen dan kelas kontrol mempunyai varians yang sama (homogen). Hipotesis yang diharapkan dalam penelitian ini adalah rata-rata kemampuan berpikir matematis taksonomi Bloom revisi dengan menggunakan model ARCS tidak sama dengan rata-rata kemampuan berpikir matematis berdasarkan taksonomi Bloom revisi dengan menggunakan metode konvensional.

Berdasarkan hasil perhitungan uji-t yang telah dilakukan menunjukkan bahwa $\mathrm{H}_{0}$ ditolak dan $\mathrm{H}_{1}$ diterima sehingga kesimpulannya rata-rata kemampuan berpikir matematis berdasarkan taksonomi Bloom revisi dengan menggunakan model ARCS tidak sama dengan rata-rata kemampuan berpikir matematis taksonomi Bloom revisi dengan menggunakan metode konvensional. Hal ini bisa disebabkan oleh faktor-faktor yang mempengaruhi tingginya rata-rata kemampuan berpikir matematis taksonomi Bloom pada kelas eksperimen di SMA Negeri 14 Bandar Lampung adalah model pembelajaran yang dapat menarik perhatian peserta didik dalam proses pembelajaran sehingga peserta didik lebih fokus dalam menerima materi yang diajarkan, terdapat dalam komponen Attention. Kesesuaian materi pembelajaran dengan kehidupan sehari-hari peserta didik serta melalui pendekatan yang berpusat pada siswa sehingga dapat melatih tingkat berpikir matematis peserta didik, terdapat dalam komponen Relevance. Memberikan bimbingan kepada peserta didik dalam mengerjakan soal latihan, hal ini dapat meningkatkan kemampuan berpikir matematis dan meningkatkan rasa kepercayaan diri peserta didik terhadap kemampuan yang dimiliki, termasuk dalam komponen Confidence. Memberikan penambahan 
nilai, pujian atau reward kepada peserta didik dapat memotivasi peserta didik dalam proses pembelajaran, termasuk dalam komponen Satisfaction. Hal ini menunjukan bahwa ada pengaruh model ARCS dalam pembelajaran matematika terhadap kemampuan berpikir matematis berdasarkan taksonomi Bloom revisi peserta didik kelas XI IPA SMA Negeri 14 Bandar Lampung. Hal ini sesuai dengan pendapat Siti Masfuah bahwa melalui pembelajaran ARCS dapat meningkatkan kemampuan pemecahan masalah dan motivasi berprestasi siswa. Dimana kemampuan pemecahan masalah merupakan salah satu indikator dari berpikir matematis. Hal tersebut juga didukung oleh pendapat Made Wena bahwa model ARCS lebih unggul dibandingkan dengan model konvensional.

\section{SIMPULAN DAN SARAN}

Berdasarkan analisis data dan uji hipotesis yang telah dilakukan maka dapat disimpulkan bahwa terdapat pengaruh model pembelajaran Attention, Relevance, Confidence, andSatisfaction (ARCS) terhadap kemampuan berpikir matematis berdasarkan taksonomi Bloom revisi. Hal ini juga terlihat pada nilai rata-rata hasil tes kemampuan berpikir matematisberdasarkan taksonomi Bloom revisi peserta didik yang diterapkan dengan model pembelajaran Attention, Relevance, Confidence, and Satisfaction (ARCS) lebih tinggi dari pada rata-rata hasil tes kemampuan berpikir matematis berdasarkan taksonomi Bloom revisi peserta didik yang diterapkan dengan model pembelajaran konvensional. Berdasarkan hasil penelitian tersebut, kamu memiliki masukan untuk guru atau pendidik dapat memilih model yang sesuai untuk meningkatkan jasil belajar peserta didik. Sedangkan masukan bagi calon peneliti lain agar dapat mengembangkan penelitian ini agar lebih baik lagi diantaranya dengan memilih kemampuan lain yang dianggap dimiliki peserta didik yang dapat diterapkan dengan model ARCS.

\section{DAFTAR PUSTAKA}

Achmad Mujahid, Analisis Kemampuan berpikir Matematika Siswa Berdasarkan Taksonomi Bloom Revisi, Tesis Magister Pendidikan Program Pascasarjana Universitas Terbuka 2015.

Aleks Maryunis, Konsep Dasar Penerapan Statistika dan teori Probabilitas, Fakultas Matematika dan Ilmu Pengetahuan Alam Universitas Negeri Padang, 2007.

Anas Sudijono. Pengantar Evaluasi Pendidikan. Jakarta: PT.Raja Grafindo Persada , 2013.

Aryadi Wijaya. Pendidikan Matematika Realistik Suatu Alternatif Pendekatan Pembelajaran Matematika. Yogyakarta: Graha Ilmu, 2012.

H.Hendriana, U.Sumarmo. Penilaian Pembelajaran Matematika. Bandung : PT Refika Aditama, 2014.

Hamoraon. "Pembelajaran Inovatif Model ARCS Keller". (On-line), tersedia di http://learningtheori.wordpress.com/2010/03/08/model-arcs-keller (06 Desember 2016).

Harina Fitriyani. "Profil Berfikir Matematis Rigor Siswa SMP dalam Memecahkan Masalah Matematika ditinjau dari Perbedaan Kemampuan Matematika". Jurnal Pendidikan Matematika, Ilmu Matematika, dan Matematika Terapan (2013).

Hermann Astleitner, "The Effects of ARCS-Strategies on Self-Regulated Laerning with Intructional Texts", Journal Departement of Education Research Akademiestrasse, 2012.

Indra Martha Rusmana, "Efektivitas Penggunaan Media ICT Dalam Peningkatan Pemahaman Konsep Matematika", Jurnal Formatif ISSN : 2088-351X. 
JohnW.Creswell, Reseach Design: Pendekatan Kuliatitatif, Kuantitatif, dan Mixed, Yogyakarta : Pustaka Pelajar, 2012.

Made Wena. Strategi Pembelajaran Inovatif Kontemporer.Jakarta : Bumi Aksara, 2013.

Mary Kay Stein, Barbara W.Grover, Marjorie Heningsein, "Building Students Capacity for Mathematical Thinking and Reasoning: An analysis of Mathematical Taks Used in Reform Classroom", American Education Research Journal (13 Januari 2013).

Maya Evy Stevany. "Pengaruh Strategi ARCS (Attention, Relevance, Confidence and Satisfaction) Terhadap Motivasi dan Hasil Belajar TIK Siswa Kelas VIII di SMP Negeri 4 Negara". Jurnal Program Pascasarjana Universitas Pendidikan GaneshaVol.4 (2014).

Maya Kusuma Ningrum dan Abdul Aziz Saefudin, "Mengoptimalkan Kemampuan Berpikir Matematika Melalui Pemecahan Masalah Matematika, Prosiding Seminar Nasional Matematika (10 November 2012) ISBN : 978-979-16353-8-7.

Mary Kay Stein, Barbara W.Grover, Marjorie Heningsein, "Building Students Capacity for Mathematical Thinking and Reasoning: An analysis of Mathematical Taks Used in Reform Classroom", American Education Research Journal (13 Januari 2013).

NCTM, "Program for Intial Preparation of Mathematics Teacher", (Online), tersedia di:http//www.ncate.org/LinkClick.aspx?fileticket $=\%$ Frfx5Ju56RY\%3D\&TABID $=676$.

Novalia, dan Muhammad Syazali. Olah Data Penelitian Pendidikan. Bandar Lampung: Anugrah Utama Raharja, 2014.

Rani Aprilyanasari. Pembelajaran Sistem Peredaran Darah Pada Manusia Dengan Model Arcs (Attention, Relevance, Confidence, Satisfaction) Didukung Multimedia Interaktif Di SMPN 1 Sumowono. Skripsi UNES : Jurusan Biologi Fakultas Matematika dan Ilmu Pengetahun Alam, 2011.

Renny Marlina. "Pembelajaran Matematika Yang Menyenangkan Melalui Pendekatan Pendidikan Matematika Yang Realistik (PMR) dalam upaya meningkatkan kemampuan berfikir matematis peserta didik SMPN 2 Talang UBI”. Jurnal SNAPTIKA(Palembang 2015).

Sangeeta Malik, "Effetiveness of ARCS of motivational design to overcome non completion rate of students in distance education", Turkish Online Journal of Distance Education (April 2014).

Siregar, Eveline, dan Hartini Nara. Teori Belajar dan Pembelajaran. Bogor : Ghalia Indonesia, 2011.

Siti Masfuah. "Pictorial Riddle Melalui Pembelajaran Attention,Relevance,Confidence,and Satisfaction (ARCS) Untuk Meningkatkan Kemampuan Pemecahan Masalah dan Motivasi Berprestasi Siswa".Jurnal KonselingGUSJIGANG Vol. 2No.1 (Januari-Juni 2016).

Suharsimi Arikunto. Dasar-Dasar Evaluasi Pendidikan, Jakarta: Bumi Aksara, 2011.

Sumarmo, "Berpikir dan Disposisi Matematika: Apa, Mengapa, dan Bagaimana Dikembangkan pada Peserta Didik", Jurnal FMIPA UPI (2010).

T.Jumaisyaroh, dkk. "Peningkatan Kemampuan Berfikir Kritis Matematis dan Kemandirian belajar Siswa SMP melalui Pembelajaran Berbasis Masalah". jurnal kreano Jurusan Matematika FMIPA UNNES Vol.5 No.2 (Desember 2014).

Tatang Herman. "Pembelajaran Berbasis Masalah Untuk Meningkatkan Kemampuan Penalaran Matematis Siswa SMP”.Jurnal Cakrawala Pendidikan Th.XXVI No.1 (Februari 2007). 
Tria Muharom, "Pengaruh Pembelajaran Dengan Model Kooperatif Tipe STAD Terhadap Kemampuan Penalaran Dan Komunikasi Matematik Peserta Didik Di SMK Negeri Manonjaya Kabupaten Tasikmalaya, Jurnal Pendidikan dan Keguruan Vol. 1 No. 1, 2014.

Peraturan Pemerintah Republik Indonesia, "Standar Nasional Pendidikan”, RPP_SNP (24 April 2005, tersedia di: http://guru-indonesia.net.

Wasukree Sangpom, et. Al. "Advanced Mathematical Thingking and Students' Mathematical Learning: Reflection from Students' Problem-Solving in Mathematics Classroom”, Journal of Education and Learning, (22 April 2016).

Wina Sanjaya. Perencanaan dan Desain Sistem Pembelajaran. Bandung : Kencana Prenada Media Group , 2008.

Wiratna Sujarweni, Metodologi Penelitian Lengkap, Praktis, dan Mudah Dipabami Yogyakarta: Pustaka Baru Press, 2014.

Yuhasriati. 'Pendekatan Realistik dalam Pembelajaran Matematika". Jurnal PeluangVol.1 No.1 (Oktober 2012).

Zulfira Irsyaf. "Penerapan Model Pembelajaran ARCS Untuk Meningkatkan Hasil Belajar Siswa Kelas VIII SMP Labschool Universitas Tadulako Pada Materi Sudut-Sudut Segitiga".Jurnal Elektronik Pendidikan Matematika Tadulako Vol.1 No 2 (Maret 2014). 
Numerical: Jurnal Matematika dan Pendidikan Matematika, Vol. 1 No. 1 Juni 2017, 15-24

Resti Yelma Sari, Netriwati, Fraulein Intan Sari

[Halaman ini sengaja dikosongkan] 